\title{
LÓDZCY ROBOTNICY Z TRZECH PERSPEKTYW OGLĄDANI UWAGI NA MARGINESIE KSIĄŻKI: KAMIL ŚMIECHOWSKI, MARTA KOWALSKA-SIKORSKA, KENSHI FUKUMOTO, ROBOTNICY LODZI DRUGIEJ POLOWY XIX WIEKU. NOWE KIERUNKI BADAWCZE ${ }^{1}$
}

\begin{abstract}
Nauka, to permanentny rewizjonizm wobec zastanego stanu wiedzy, wynikający z twórczej nieufności, to procedura badawcza rygorystycznie sprawdzalna.
\end{abstract}

Tadeusz Łepkowski

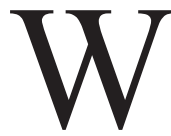

polskim piśmiennictwie historycznym zauważalny staje się powrót do różnie ukierunkowanych badań nad środowiskami robotniczymi epoki kapitalizmu. Podejmują je przedstawiciele pokolenia, dla którego dawne ujęcia tej problematyki są już niewystarczające poznawczo. Miejsce eksponowanej niegdyś ,walki klas” zajmują dziś nowe, różnorodne perspektywy badawcze, wynikające z rozwoju nauk historycznych i społecznych.

Jedną z najnowszych takich prób jest opracowanie autorstwa Kamila Śmiechowskiego, Marty Sikorskiej-Kowalskiej i Kenshi Fukumoto, pod obiecującym tytułem Robotnicy Łodzi drugiej połowy XIX wieku. Nowe kierunki badawcze. Wypełniają je trzy teksty, przynoszące jak na 122 stronicowy utwór, imponujący katalog pytań badawczych. Deklarowane przez Zespół autorski nowatorstwo książki oraz wyżej przywołany podtytuł, budzą po pierwsze ciekawość, na czym to nowatorstwo polega, po drugie - zachęcają do zweryfikowania zaprezentowanych tez. Wbrew użytemu we ,Wstępie” twierdzeniu, książka nie jest monografią (s. 8). Żadnego z tekstów nie można też nazwać ,,artykułem monograficznym” (s. 8-9). Od artykułu monograficznego oczekuje się, by przedstawiał jedno zagadnienie w sposób wyczerpujący i udokumentowany, i aby był zgodny z najaktualniejszymi wynikami badań innych naukowców. Żaden z tekstów zawartych w książce kryteriów tych nie spełnia. Mamy zatem do czynienia z pracą zbiorową, łączącą

${ }^{1}$ K. Śmiechowski, M. Sikorska-Kowalska, K. Fukumoto, Robotnicy Łodzi drugiej połowy XIX wieku. Nowe kierunki badawcze, Wydawnictwo Uniwersytetu Łódzkiego, Łódź 2016, ss. 122. 
pod wspólnym tytułem trzy teksty o charakterze wielowątkowych szkiców i obywającą się bez redaktora, czego efekty wskazane zostaną dalej.

Kluczowe dla zrozumienia konstrukcji książki jest przypisane Jerzemu Jedlickiemu twierdzenie, że uprzemysłowienie Królestwa Polskiego miało „wyspowy, quasi-kolonialny charakter", co przesądzało o charakterze fenomenu społeczno-politycznego, którym u progu XX w. stała się klasa robotnicza (s.14). W rzeczywistości J. Jedlicki stwierdził:

\section{główny tor uprzemysłowienia Królestwa przyjąl kierunek quasi kolonialny [podkr. - K.P.W.], w niewielkim stopniu zależny od miejscowych źródeł akumulacji i płytko oddziaływający na zakonserwowane struktury społeczne [podkr. K.P.W.].}

Przyjęcie kierunku przemian nie oznacza, że się one dokonały, ale jeszcze ważniejsza jest konstatacja, że ich wpływ na zmianę struktury społecznej był powierzchowny, co musi być odczytane jako imperatyw dla badań bardzo szczegółowych, wręcz drobiazgowych, z odwołaniem się do różnych typów źródeł, aby zmiany te dostrzec, opisać, zinterpretować. Przypomnieć trzeba, że termin „kapitalizm wyspowy" wprowadził do polskiej historiografii Witold Kula:

Kapitalizm w Polsce miał w dużej mierze charakter wyspowy i półkolonialny, półkolonialny, gdyż ziemie polskie były traktowane jako lokata zagranicznych kapitałów. Lokata nieraz na krótką metę, nieraz nawet przejściowa ${ }^{2}$.

Wniosek z tego oczywisty, że owa ,półkolonialność” nie dotyczyła sfery społecznej, co potwierdził J. Jedlicki. Dlatego analizowanie relacji zachodzących w społeczeństwie polskim epoki kapitalizmu ,z perspektywy postkolonialnej”, stosowanej wobec społeczeństw i narodów, które przeszły w swoich dziejach kolonizację, jest zabiegiem chybionym.

W miejsce podjęcia możliwych do realizacji studiów przypadków, dających możliwości szerszych uogólnień, Autorzy poprzestali na dość ogólnikowych i nie zawsze trafnych relacjach, opartych głównie na źródłach prasowych i literackich, niedostatecznie weryfikowanych i przywoływanych jako ilustracje do założonych przez siebie tez. W efekcie czytelnik nie otrzymał odpowiedzi, jaka była Łódź i mieszkający w niej na przełomie XIX i XX w. robotnicy, ale dowie się, jak chcą ją widzieć Autorzy, wyposażeni w narzędzia i metody zaczerpnięte z różnych współczesnych szkół badawczych (z dość tajemniczo brzmiącym odwoływaniem się do „klasycznych prac z zakresu socjologii miasta” - s. 8) i mód intelektualnych. W lekturze nietrudno dostrzec fascynacje współczesnymi ruchami miejskimi (s. 28), ideologią gender czy też teorią postkolonialną. Podstawowe pytania,

${ }^{2}$ Cyt. za: Stenogram konferencji Polskiego Towarzystwa Ekonomicznego, ,Polska szkoła socjologii historycznej i historii gospodarczej: Witold Kula, Marian Małowist”, Warszawa, 11 czerwca 2013 r., s. 16 (http://www.pte.pl/243_konferencje_cd.html - dostęp: 9.04.2016). 
które trzeba postawić, brzmią: czy wszystkie te narzędzia użyto wobec prawidłowo zrekonstruowanej rzeczywistości historyczno-kulturowej i czy wybrano narzędzia i metody właściwe.

Tekst autorstwa K. Śmiechowskiego, zatytułowany Łódź przełomu wieków XIX i XX-miasto robotników? przynosi w siedmiu podrozdziałach taką ilość zasygnalizowanych problemów, że mogłyby one, przy rzetelnej analizie, wypełnić obszerny tom. Zamierzeniem Autora było udzielenie odpowiedzi na pytanie o miejsce społeczności robotniczej w życiu przemysłowego miasta (s. 8). Nie ma w tekście zapowiedzianych rozważań nad relacjami między poszczególnymi warstwami społecznymi. Pojawiają się natomiast uwagi dotyczące warunków życia robotników i ich konsekwencji, relacji między robotnikami a inteligencją, czy też rewolucji 1905-1907 r., potraktowanej jak czas narodzin nowego miasta. Wszystko to opisane szkicowo, w oparciu przede wszystkim o „publicystykę i lokalną prasę" (s. 15), choć trudno wyobrazić sobie w opisywanej epoce publicystykę inną niż prasowa. Przede wszystkim jednak ogromne zdziwienie budzi twierdzenie Autora, że na przełomie XIX i XX w. robotnicy stanowili 70\% ogółu mieszkańców Łodzi (s. 8, 14). Szkoda, że czujności K. Śmiechowskiego nie wzbudziła cytowana przez niego opinia publicysty „Gońca Łódzkiego”, który w 1898 r. pisał, że ,przemysł łódzki zatrudnia przeszło 40000 robotników, którzy razem z rodzinami tworzą ludność co najmniej 120000 dusz" (s. 34). Ponieważ rok wcześniej liczbę mieszkańców Łodzi (wraz z Bałutami), szacowano na ok. 314 tys. osób ${ }^{3}$, to odsetek robotników kształtowałby się na poziomie ok. 38\%. Trzeba jednak zauważyć, że według innych, urzędowych szacunków, dopiero w 1914 r. liczba robotników w fabrykach łódzkich sięgnęła 100 tys. ${ }^{4}$, a wyniki badań źródłowych Juliana Janczaka, Władysława Lecha Karwackiego i Pawła Samusia nie pozostawiają wątpliwości, że w latach 1885-1912 robotnicy stanowili ok. 20\% ogółu mieszkańców Łodzi, przy czym w 1893 r. odsetek ten był maksymalnie wysoki, osiągając wartość $26,7 \%$. Między niespełna $30 \%$ a $70 \%$ różnica jest niebagatelna, a dla rozważań Autora badającego „stopień demokratyzacji przestrzeni miejskiej, ze szczególnym uwzględnieniem roli zajmowanej w niej przez robotników", zgoła fundamentalna.

Zupełnie niezrozumiałe jest stanowisko Autora deklarującego wymienne posługiwanie się terminami „klasa” i „warstwa społeczna” z uzasadnieniem, że taka była narracja źródeł przed 1905 r. Przyjęcie takiego rozwiązania oznacza cofnięcie się o pół wieku w postępie badań historycznych. Nie namawiam do

3 J. Janczak, Ludność Łodzi przemystowej 1820-1914, Łódź 1982, s. 39.

${ }^{4}$ Z. Pietkiewicz, Łódź w cyfrach, [w:] Rocznik Łódzki Gebethnera i Wolffa na rok 1914, Warszawa b.r.w., s. 180 .

5 P. Samuś, $W$ walce o wyzwolenie narodowe i społeczne (1893-1918), [w:] W dymach czarnych budzi się Łódź. Z dziejów łódzkiego ruchu robotniczego 1882-1948, Łódź 1985, s. 76; W.L. Karwacki, Sytuacja społeczno-polityczna tódzkich wtókniarzy w latach 1908-1914, [w:] Włókniarze łódzcy. Monografia, pod red. E. Rosseta, Łódź 1966, s. 76. 
powrotu w stosowaniu metodologii marksistowskiej! Do analizy problemów społeczeństwa Łodzi znakomicie przystaje weberowska typologia klasy i warstwy społecznej, i rolą historyka jest użycie jasno zdefiniowanego instrumentarium pojęciowego, zwłaszcza w problematyce, którą zaczęto badać już przed wiekiem i rozróżnienie między klasą a warstwą nie budzi dziś wątpliwości ${ }^{6}$. Próżno szukać w tekście anonsowanych rozważań nad strukturą warstwową łódzkiego proletariatu. Stanowiłyby one istotne novum, ponieważ ukształtowany w minionych dziesięcioleciach obraz wielkomiejskiego środowiska robotniczego, przedstawia je schematycznie, jako homogeniczny monolit. W to miejsce podjął Autor próbę ukazania relacji między robotnikami a inteligencją, czyli problemu badawczo rozpoznanego, znanego, a przede wszystkim wykraczającego poza relacje między warstwami społecznymi.

Podobnie znanym i w różnych aspektach poznanym jest nurtujące K. Śmiechowskiego zagadnienie miejsca robotnika $\mathrm{w}$ przestrzeni miasta ${ }^{7}$. W rozważaniach Autora brak jest odniesień do fundamentalnych prac z tego zakresu, które być może pozwoliłyby inaczej postrzegać zarówno samą przestrzeń, jak i to, co się w niej działo ${ }^{8}$. Nie można zgodzić się z twierdzeniem, że „w realiach łódzkich przestrzeń publiczna ograniczała się przede wszystkim do ulic”. Co prawda, idąc za realiami właściwymi dla Warszawy, poszerza Autor tę przestrzeń o place, targowiska i wszelkie instytucje użyteczności publicznej, ale na tym koniec. Warto więc uściślić, że w Łodzi wszystkie [podkr. K.P.W.] place pełniły rolę targowisk; innych placów nie było. Wielkich targowisk było w Łodzi przed 1914 r. sześć. To wokół nich koncentrowało się życie poszczególnych dzielnic miasta. To one, a nie ulice, stanowiły miejsce skracania dystansu między grupami społecznymi, przełamywania barier środowiskowych. Zapomina się bowiem, że handel jest najstarszą i jedną z najowocniejszych płaszczyzn kontaktów i wymiany międzykulturowej. To targowiska stanowiły ,żywe laboratorium” tworzenia i wzbogacania leksyki znanego łodzianom ,języka" Lodzer Deutsch. Analizując skład społeczny sprzedających i kupujących (wśród nich znaczny udział służby domowej) na łódzkich targowiskach, znalazłby Autor odpowiedź na pytanie o formy i zakres „demo-

${ }^{6}$ M. Weber, Gospodarka i społeczeństwo. Zarys socjologii rozumiejacej, Warszawa 2002. Zob. też: L. Gall, Stadt und Bürgertum im 19. Jahrhundert. Ein Problemaufriss, [w:] Stadt und Bürgertum im 19. Jahrhundert, hrsg. von L. Gall, München 1990, s. 1-17; tenże, Stadt und Bürgertum im Übergang von der traditionalen zur modernen Gesellschaft, [w:] Stadt und Bürgertum im Übergang von der traditionalen zur modernen Gesellschaft, München 1993, s. 1-12; tenże, Vom Stand zur Klasse? Zu Entstehung und Struktur der modernen Gesellschaft, „Historische Zeitschrift”, Bd. 261, 1995, s. 1-21.

${ }^{7}$ G.E. Karpińska, Robotnik w przestrzeni miasta, [w:] Materiaty do etnografii miasta, t. 2, pod red. A. Stawarza, Żyrardów 1993, s. 25-39; A. Dauksza, Emancypacja kobiet w przestrzeni miejskiej przełomu XIX i XX wieku, [w:] Ulica - zaułek-bruk. Z problematyki miasta w literaturze drugiej połowy XIX i początku XX wieku, pod red. K. Badowskiej i A. Janiak-Staszek, Łódź 2013, s. 167-188.

${ }^{8}$ E. Przestaszewska-Porębska, Struktura przestrzeni miejskiej, [w:] Miasto i kultura polska doby przemystowej. Przestrzeń, pod red. H. Imbs, Wrocław 1988, s. 51-76; P. Tobiasz-Lis, Zmiany wyobrażeń mieszkańców Łodzi o przestrzeni miasta, Łódź 2013, s. 23-35. 
kratyzacji przestrzeni miejskiej Łodzi” (s. 8). Ale przecież przestrzenią miejską, przestrzenią publiczną były także tereny zielone położone $\mathrm{w}$ granicach miasta i na jego obrzeżach (wokół stawu scheiblerowskiego przy ul. Przędzalnianej, na Młynku, w lasku „Szeląg” (obecny Park im. 3 Maja), w lesie na Mani). Były to miejsca gromadnie uczęszczane podczas majówek, gdzie wspólnie bawiono się, śpiewano, tańczono, najczęściej w kręgach rodzinnych, ale też sąsiedzkich, często mieszanych narodowościowo w obrębie społeczności chrześcijańskiej ${ }^{9}$. Kolejną arenę „demokratyzacji przestrzeni”, a więc skracania dystansu międzykulturowego stanowiły podwórka, zarówno kamienic czynszowych, jak i stanowiące zaplecze domów familijnych (Księży Młyn, „famuły” I.K. Poznańskiego, domy kunitzerowskie na Widzewie, domy robotnicze zakładów Allarta i Rousseau'a), czy też przylegające do wolnostojących domów czynszowych, szczególnie licznych na Bałutach. Choć zaliczane bywają formalnie do przestrzeni półpublicznej (półprywatnej), to ze względu na swoją ogólną dostępność, stanowiły przestrzeń otwartą $^{10}$. Poprzestając na opisie zdarzeń rozgrywających się na ulicach Łodzi nie sposób przedstawić dowody uzasadniające tezę Teresy Hoskyns, że „przestrzeń publiczna wytwarza stosunki demokratyczne” (s. 28). W Łodzi przełomu XIX i XX w. przestrzenią tą nie były ulice. Bezproduktywne jest poszukiwanie odpowiedzi na współcześnie sformułowane pytanie o to, komu przysługiwało ,prawo do miasta" (s. 28), ponieważ na przełomie XIX i XX w. zagadnienie takie pozostawało poza świadomością łódzkich robotników. Jeżeli szukać przestrzeni społecznej, w której zachodzić zaczęły w Łodzi procesy demokratyzacji, obniżania barier między środowiskami, warstwami, to wskazać należy instytucje, zwłaszcza działające w środowisku niemieckim i postulujące egalitaryzm społeczny ${ }^{11}$. Dopiero w licznie powstających od 1906 r. organizacjach i stowarzyszeniach, od sportowych po zawodowe, nastąpił wyraźnie widoczny proces zacierania granic środowiskowych i warstwowych ${ }^{12}$.

${ }^{9}$ Folklor robotniczej Łodzi. Pokłosie konkursu, pod red. B. Kopczyńskiej-Jaworskiej, J. Kucharskiej, J.P. Dekowskiego, Wrocław 1976, s. 119-125.

${ }^{10}$ E. Przestaszewska-Porębska, $d z$. cyt., s. 57, 66. Takie realia bałuckie potwierdza zarówno przekaz literacki, jak i autobiograficzno-wspomnieniowy: J. Rabon, Batuty. Powieść z przedmieścia, pod red. K. Radziszewskiej, N. Krynickiej, przy współpracy I. Olejnik i J. Walickiego, Łódź 2016; A. Scheffel, Lodż - historia/e, Łódź 2008.

${ }^{11}$ Doniosłą rolę odegrały świeckie i kościelne chóry niemieckie. Skupiały przedstawicieli różnych warstw społecznych i różnych zawodów. Różniło to je od chórów polskich, którym zarzucano, że charakteryzuje je: „Zaściankowa kastowość, boć urzędnikowi, choćby nawet z magistratu, w jednym chórze z rzemieślnikiem a tem mniej robotnikiem, a panu majstrowi ze swoim czeladnikiem śpiewać i grać w jednej kapeli - nie wypada” („Rozwój” 1908, nr 280, s. 8). Szerzej: K.P. Woźniak, Świeckie i kościelne chóry niemieckie w Łodzi (do 1939 r.). Organizacja - działalność - repertuar, „Studia z Historii Społeczno-Gospodarczej XIX i XX wieku”, t. 13, 2014, s. 127-141.

${ }_{12}$ B. Pietrow-Ennker, Auf dem Weg zur Bürgergesellschaft. Moderniesierungsprozesse in Lodz (1820-1914), [w:] Polen, Deutche und Juden in Lodz 1820-1939, hrsg. von J. Hensel, Osnabrück 1999, s. 126-128. 
Nader prosto można też wytłumaczyć, czemu Łódź kojarzona była częściej $\mathrm{z}$ „miastem fabryk”, niż „miastem robotników” i będzie to wyjaśnienie dalekie od poszukiwania form oswajania przestrzeni miejskiej przez proletariuszy. Łódź stała się „miastem fabryk”, ponieważ to one pojawiały się w krajobrazie miasta nagle, niemal deus ex machina. Cykl inwestycyjny największych budynków fabrycznych rzadko przekraczał dwa lata. Liczba przedsiębiorstw fabrycznych kontrolowanych przez Inspekcję Fabryczną wzrosła od 425 w 1901 r. do 795 w 1912 r., zatem w ciągu dekady liczba fabryk niemal podwoiła się! ${ }^{13}$ Nie dziwi zatem zwrot niemal do znudzenia powtarzany w źródłach i opracowaniach niemieckich: „die Fabriken schossen wie die Pilze aus dem Boden”, bo to fabryki stanowiły dominantę w przestrzeni Łodzi. Były widoczne w dzień, były widoczne w nocy. Robotnicy, jako grupa społeczna nie pojawili się równie nagle. W okresie od końca XIX w. do 1914 r. ok. 40\% robotników łódzkich rekrutowało się ze wsi ${ }^{14}$. „Wrastali w miasto" w toku pokoleniowego procesu, mającego także swój wymiar przestrzenny (od peryferii ku centrum), stosunkowo dobrze już poznanego i opisanego przez historyków i etnografów ${ }^{15}$. W przestrzeni miasta pojawiali się w zauważalny sposób na krótko, przed i po zakończeniu pracy.

Fascynacja przekazami literackimi skłoniła K. Śmiechowskiego do obszerniejszych rozważań nad codziennymi ,pochodami”, „,przemarszami” robotników ulicami Łodzi. Jak pisze Autor: „Codzienne robotnicze pochody ulicami miasta miały pewien charakter demonstracyjny i podkreślały obecność większości mieszkańców miasta w jego przestrzeni” (s. 27). Co więcej „robotnicy i robotnice mieli jednak pojawiać się na głównej ulicy miasta [Piotrkowskiej - przyp. K.P.W.] w określonym rytmie, odpowiadającym rytmowi syren fabrycznych" (s. 26). Frazy to ładne, wabiące plastyczną wizją scen gotowych do przeniesienia na plan filmowy, niestety, w całości nieprawdziwe. Pomijając wskazany na wstępie błąd szacunku liczebności proletariatu łódzkiego (nie stanowił ,większości mieszkańców miasta w jego przestrzeni”), zapytać trzeba, co mieliby demonstrować wychodzący z fabryki i spieszący do swoich mieszkań robotnicy? Te literackie wizje najbliższe są obrazowi „Wyjścia robotników z fabryki”, sfilmowanemu w 1895 r. przez braci Lumière w Lyonie, a jest to sekwencja dziejąca się w przestrzeni nie odleglejszej od fabrycznej bramy niż 50 metrów. Dalej robotnicy rozchodzą się grupami, podążają w różnych kierunkach, poszczególne grupki atomizują się. Tak było i w Łodzi, co potwierdzają materiały etnograficzne i przekazy literackie

13 J. Janczak, dz. cyt., Łódź 1982, s. 168.

${ }^{14}$ P. Samuś, dz. cyt., s. 78.

${ }^{15}$ Z obszernej literatury wskazać można: P. Samuś, dz. cyt., s. 78-80; A. Lipiński, Pozostałości kultury tradycyjnej w łódzkich rodzinach robotniczych, „Łódzkie Studia Etnograficzne”, t. 7, 1965, s. 5-39; I. Lechowa, Tradycyjne zwyczaje świateczne $w$ tódzkim środowisku robotniczym (1890-1939), „Prace i Materiały Muzeum Archeologicznego i Etnograficznego w Łodzi”. Seria Etnograficzna, 1967, nr 11, s. 133-162; A. Woźniak, Społeczne funkcje obrzędowości dorocznej w środowisku robotników łódzkich, „Acta Universitatis Lodziensis. Folia Ethnologica”, t. 5, 1991, s. 27-54. 
- ,wreszcie cała ta masa rozlewa się po sąsiednich ulicach”16. Jakie zatem „robotnicze pochody ulicami miasta" ma autor na myśli? Podpowiem: w ten sposób wracano z podmiejskich majówek, ale też nie ulicą Piotrkowską ${ }^{17}$.

Wydaje się, że wszyscy Autorzy dyskutowanej tu książki zauroczyli się łódzką publicystyką i, generalnie, przekazem literackim. Istotą publicystyki jest jej subiektywny charakter, tymczasem pod piórami Autorów dawne relacje otrzymały rangę przekazów obiektywnych. Jeszcze bardziej jest to widoczne przy odwołaniach do literatury beletrystycznej. Kreślone w niej obrazy „z życia” mieszkańców Łodzi nie zostały poddane daleko idącej krytyce, która mogłaby je oczyścić zarówno z manier literackich epoki, jak i z częstego w niej dydaktyzmu. Trudno oprzeć się wrażeniu, że zarówno reymontowska wizja „ziemi obiecanej”, jak i „złe miasto" Z. Bartkiewicza, traktowane są jako fotografie XIX-wiecznej rzeczywistości. Zdumiewa przy tym twierdzenie K. Śmiechowskiego, że „oba te epitety miały określać pogoń za zyskiem, zanik moralności i olbrzymi stopień wyzysku” (s. 13). Tak jednostronnego odczytania określenia „ziemia obiecana” nikt jeszcze nie proponował! Może warto sięgnąć do lektur pominiętych? ${ }^{18}$

Zmitologizowany literacko obraz ul. Piotrkowskiej, jako centrum i „serca" miasta nie wytrzymuje też konfrontacji ze źródłami oral history, które doskonale współbrzmią choćby z opinią Arnolda Mostowicza. Odnosząc się do czasów o ćwierć wieku późniejszych, to jest lat 20. i 30. XX w. twierdził on, że nie istniała jedna Łódź. Była Łódź Bałut, Łódź Śródmieścia, Łódź Chojen (zapewne i innych dzielnic), których mieszkańcy rzadko wykraczali poza ich granice ${ }^{19}$. W ich obrębie znajdowały się przecież wszystkie instytucje niezbędne do codziennego życia. Racjonalne było też zamieszkanie możliwie blisko miejsca pracy. Wymuszał to bilans czasu przeznaczanego na pracę zawodową (do 1906 r. 11,5 godziny) i na wypoczynek. Do domów wracano najkrótszą drogą. Odmianę przynosiły niedziele i dni świąteczne, ale czego wówczas mieliby robotnicy szukać na ulicy Piotrkowskiej? Silny partykularyzm dzielnicowy potwierdzają np. wyniki badań nad łódzkimi kapelami podwórkowymi. Nie wykraczały ze swoimi produkcjami poza granice „swoich rewirów” głównie dlatego, że prezentowany przez nie repertuar nie znajdował uznania w odleglejszych rejonach miasta ${ }^{20}$. Trzeba przyjąć jako pewnik, że mobilność robotników w dniach pracy była niewielka.

${ }^{16}$ X.Y.Z. [właściwie: A. Mieszkowski i A. Glisczyński], Łódź w obrazkach, cz. I, „Goniec Łódzki" 1898, nr 17, s. 3.

${ }^{17}$ Folklor robotniczej Łodzi..., s. 134.

${ }^{18}$ M. Romankówna, „Ziemia obiecana” Reymonta a rzeczywistość łódzka, „Prace Polonistyczne” 1937, nr 1; J. Fiszbak, Mity „ziemi obiecanej” w regionalnej literaturze Łodzi. Między gra wyobraźni, fikcja literacka a historia, Łódź 2013, s. 113-145.

19 A. Mostowicz, Żółta gwiazda i czerwony krzyż, Warszawa 1988, s. 69.

${ }^{20}$ K.P. Woźniak, „Hauzeracy idą!”. Piosenka na tódzkim podwórku, „Zeszyty Wiejskie”, t. 22, 2016, s. 212. 
Miejskie partykularyzmy w Łodzi są historycznym faktem, wykraczającym daleko poza rok 1905, 1914, czy kolejne, znaczące w dziejach miasta daty. Wbrew twierdzeniu Autora (s. 44), rewolucja 1905-1907 niczego w tej mierze nie zmieniła. Można zaryzykować twierdzenie, że świadomość odrębności dzielnicowych zachowała się w Łodzi do dziś i co więcej, nie stanowi ona specyfiki tego miasta ${ }^{21}$. Na przełomie XIX i XX w. robotnicy berlińskiej dzielnicy Wedding nie zapuszczali się do eleganckiego Charlottenburga, a zielony Wilmersdorf mogli odwiedzać w niedziele. Owszem, identyfikowali się z Berlinem, ale go nie znali.

Nieprawdziwy jest, podany za literackim przekazem, obraz robotników udających się do podrzędnego szynku w towarzystwie współwłaściciela znacznej, bo zatrudniającej „do 200 robotników” fabryki, przywołany jako dowód „demokratyzacji przestrzeni miejskiej” (s. 28). Rozległe i wykorzystujące różne kategorie źródeł badania nad środowiskiem łódzkich majstrów włókienników pokazują dobitnie, że obie te grupy dzielił ogromny dystans ${ }^{22}$. Cóż dopiero mówić o nieprzystawalności światów, realizowanych wzorów zachowań robotnika i drobnego (200 zatrudnionych) bourgeoise'a. Jeszcze w latach 30. XX w. nie wyobrażano sobie biesiadowania grupy robotników z udziałem majstra. Były to całkowicie odrębne środowiska. Szkoda, że to, co w szkicu K. Śmiechowskiego rzeczywiście interesujące, zostało zaledwie zarysowane grubą kreską, jak choćby odniesienia do tez Manuela Castellsa (s. 24-25), nota bene wprowadzonych do polskiego obiegu naukowego już trzy dekady temu, ale nadal przecież aktualnych ${ }^{23}$.

Tezę o przełomowym znaczeniu wydarzeń lat 1905-1907 dla kształtowania się świadomości nie tylko klasowej proletariatu, w tym łódzkiego, sformułowano już dość dawno, ale nie została ona odpowiednio rozpropagowana, ani nie poszły w ślad za nią pogłębione prace badawcze ${ }^{24}$. Dopiero ostatnie lata przyniosły wzrost zainteresowania tą problematyką i w ślad za nim wartościowe publikacje $\mathrm{e}^{25}$. Wbrew twierdzeniu K. Śmiechowskiego, rewolucja 1905 r. nie stanowi cezury

${ }^{21}$ P. Tobiasz-Lis, Zmiany wyobrażeń mieszkańców Łodzi o przestrzeni miasta, Łódź 2013, s. $112-118$.

${ }^{22}$ K. Woźniak, Między robotnikiem a fabrykantem. Społeczność łódzkich majstrów włókienniczych (od lat 80. XIX w. do 1939 r.), [w:] Wspólnoty lokalne i środowiskowe w miastach i miasteczkach ziem polskich pod zaborami i po odzyskaniu niepodległości, pod. red. M. Nietykszy, Toruń 1998, s. 251-265.

${ }_{23}$ B. Jałowiecki, Miasto w dobie przemystowej. Uwagi o podejściu systemowym, [w:] Miasto $i$ kultura..., s. 27-49.

${ }^{24}$ T. Fuchs, K. Woźniak, Auf die Strasse, Brüder! Als Polen, Juden und Deutsche gemeinsam gegen die Unterdrückung kämpften. Eine Betrachtung Lodzer Revolution von 1905 aus interkultureller Sicht, "1999. Zeitschrift für Sozialgeschichte des 20. und 21. Jahrhundert", 1997, H. 1, s. 13-28.

${ }^{25}$ Rewolucja 1905. Przewodnik krytyki politycznej, pod red. K. Piskały i W. Marca, Warszawa 2013; W. Marzec, Rebelia i reakcja. Rewolucja 1905 roku i plebejskie doświadczenie polityczne, Łódź-Kraków 2016. Zob. też uwagi P. Waingertnera, Najnowsza książa Wiktora Marca, „Kronika Miasta Łodzi” 2016, nr 4, s. 199-203. 
znoszącej ograniczenia w ,programie modernizacji miast” Królestwa Polskiego. W latach 1905-1914 nie można wskazać w Łodzi żadnej inwestycji, która służyłaby modernizacji rozumianej jako wzbogacanie miasta w zakresie infrastruktury. Wszystkie najważniejsze zrealizowano przed 1905 r. Od 1876 r. istniała Ochotnicza Straż Pożarna. Już w 1898 r. uruchomiono komunikację tramwajową, systematycznie rozbudowywaną, włącznie z budową linii do dwóch największych okolicznych miast: Pabianic i Zgierza (1901 r.). Rok później oddano do użytku linię kolei kaliskiej. Od 1903 r. opracowywano plan wodociągów i kanalizacji, zrealizowany dopiero w Polsce Odrodzonej. W latach 1898-1905 oddano do użytku trzy szpitale: gruźliczy, pediatryczny, psychiatryczny; w kolejnych 9 latach żaden nowy szpital nie powstał. Przed 1905 r. zorganizowano też sieć ambulatoriów przeznaczonych dla robotników tych fabryk, których właściciele nie zapewniali pomocy lekarskiej. Od 1899 r. funkcjonowało Pogotowie Ratunkowe zorganizowane dzięki środkom społecznym. Nie miejsce tu na odniesienie się do cytowanej za Agatą Zysiak i Wiktorem Marcem dość fantazyjnej tezy o „carskim wariancie kapitalizmu”, wiążącym się z ,abdykacją państwa z wypełniania wielu funkcji publicznych" (s. 36-37). W odniesieniu do Królestwa Polskiego problem jest daleko bardziej złożony. Wystarczy przypomnieć inwestycje zrealizowane w Warszawie za czasów prezydentury Sokrata Starynkiewicza (1875-1892) i przekształcające ją w nowoczesny, w realiach ostatniej ćwierci XIX w., organizm miejski, by tę arbitralną opinię skutecznie podważyć ${ }^{26}$. Wśród przyczyn zaniedbań łódzkich widzieć trzeba zarówno brak osobowości na miarę Starynkiewicza wśród włodarzy miasta, jak i mimo wszystko relatywnie małe zaangażowanie miejscowej, wielonarodowej burżuazji w sprawy publiczne ${ }^{27}$.

Z wywodów K. Śmiechowskiego poświęconym rewolucji 1905-1907 r. trudno wywnioskować, czy robotnicy „ponieśli klęskę” (s. 44), czy też „rewolucję [...] przegrali, zarówno na poziomie fabryki, jak i na poziomie ulicy" (s. 42), czy jednak „zyskali podmiotowość polityczną” (s. 43), co musi być przecież jednoznacznie ocenione jako sukces o dalekosiężnych konsekwencjach. Ocena rewolucji budzi sprzeczne opinie od zarania poddawania jej historycznej analizie. Zdaniem Tomasza Kizwaltera była rewolucją przegraną, ale ta porażka mierzona jest skalą robotniczych oczekiwań i postulatów ${ }^{28}$. Z drugiej strony mamy zupełnie inną ocenę jej wnikliwego badacza, Feliksa Tycha ${ }^{29}$. Szkoda, że K. Śmiechowski pominął

\footnotetext{
${ }^{26}$ A. Słoniowa, Sokrates Starynkiewicz, Warszawa 1981; S. Starynkiewicz, Dziennik 1887/1897, Warszawa 2012; http://www.ipsb.nina.gov.pl/a/biografia/sokrat-starynkiewicz.

${ }^{27}$ K.P. Woźniak, Burżuazja łódzka, polska, europejska w XIX wieku. Podobieństwa i różnice, [w:] Imperium Poznańskich. Przywrócone dziedzictwo czasu i miejsca, pod red. M. Jakóbczyk, K. Kuropatwy-Pik, C. Pawlaka, Łódź 2012, s. 47-65.

${ }^{28} \mathrm{http}: / /$ kulturaliberalna.pl/2017/04/04/marzec-rebelia-reakcja-recenzja-kizwalter/.

${ }^{29}$ To pierwszy zryw wolnościowy, którego zakończenie nie oznaczało pogorszenia sytuacji Polaków... Z Feliksem Tychem rozmawia Kamil Piskała, [w:] Rewolucja 1905. Przewodnik krytyki politycznej..., s. 44-66.
} 
wywalczone przez robotników skrócenie czasu pracy i podwyżkę wynagrodzeń, średnio o $20 \%$. Te zdobycze trudno chyba określić jako przegraną „na poziomie fabryki”.

Tekst pióra Marty Sikorskiej-Kowalskiej, zatytułowany Armia nowoczesnych niewolnic. Robotnice w Łodzi przetomu XIX i XX wieku, zarekomendowany został jako łączący „kwestię robotniczą” z „kwestią kobiecą” (s. 9). Autorka zajęła się $\mathrm{w}$ nim problemami związanymi z zatrudnianiem kobiet $\mathrm{w}$ fabrykach, ukazaniem miejsca robotnic $\mathrm{w}$ życiu politycznym oraz w życiu codziennym, kwestią feminizacji biedy, zagadnieniem segregacji zawodowej determinowanej płcią oraz sposobem spędzania wolnego czasu i rolą ubioru. W sumie są to zagadnienia, o których Autorka już wielokrotnie, w różnych miejscach pisała. Badania „,z perspektywy kobiecej" uprawiane są w obrębie wielu dyscyplin od długiego już czasu, trudno je nazywać kierunkiem nowym, tym większa zatem ciekawość, co nowego oferuje Autorka czytelnikowi w najnowszym swoim opracowaniu.

Przed wielu już laty Halina Gerlich, jedna z prekursorek badań w typie gender studies, trafnie zauważyła, że badacze podejmujący badania z perspektywy kobiecej „manifestacyjnie wskazują na „podległość” kobiety, ale nie starają się już odzwierciedlić i opisać innych aspektów jej pozycji”" ${ }^{30}$. Ta sytuacja utrzymuje się nadal, przede wszystkim z powodu niepodejmowania koniecznych, drobiazgowych studiów przypadku (case studies, Fallstudien), które pozwoliłyby dostrzec wewnętrzne zróżnicowania jednolitych z pozoru grup społecznych, w analizowanym tu tekście „włókniarek”, „robotnic”. Ten deficyt jest także wyraźnie widoczny w badaniach nad całym społeczeństwem Łodzi epoki kapitalizmu. Zaważył też na sposobie opisu i wnioskach sformułowanych przez M. Sikorską-Kowalską.

Dla zrozumienia sytuacji kobiet w przemyśle łódzkim w sposób wychodzący poza łączenie jej z uwarunkowaniami formalno-prawnymi i kulturowymi (realizowany wzór życia zgodny z kulturą tradycyjną), mocno zaakcentować trzeba zasadnicze różnice występujące między wielkimi, wielowydziałowymi przedsiębiorstwami włókienniczymi, a zakładami małymi, obejmujący jeden wydział, np. tkalnię i to często jedynie dzierżawioną. Taka sytuacja prawna rodziła zupełnie inny stosunek dzierżawcy do budynku, maszyn i zatrudnionych, pracujących w nieporównanie i pod każdym względem gorszych warunkach niż w fabrykach wielkich. Pozycja pracujących w nich kobiet była więc z natury rzeczy słabsza,

${ }^{30} \mathrm{H}$. Gerlich, „Głos mamulki byt zawsze najważniejszy”. Uwagi etnologa o pozycji kobiety w rodzinie górniczej, [w:] Materiały do etnografii miasta, cz. 3, pod red. A. Stawarza, Żyrardów 1994, s. 58. Taki sposób narracji pozwala pisać np., że kobiety „pracowały w bardzo trudnych warunkach oraz narażone były na choroby zawodowe", jak gdyby warunki pracy mężczyzn były inne, a choroby ich omijały. 
stosunek ,podległości” musiał i zapewne był bardziej odczuwalny. Nie jest możliwe rzetelne prześledzenie relacji międzyludzkich (we wszystkich ich wymiarach: dystansu między płciami, zależności służbowych itd.) w wielkim zakładzie przemysłowym (czy też relacji zachodzących w środowisku zatrudnionych w wielu tego typu przedsiębiorstwach), bez zrozumienia zasad i mechanizmów funkcjonowania wielowydziałowego przedsiębiorstwa przemysłowego, $\mathrm{w}$ interesującym nas zakresie - włókienniczego. Pomijając mało istotną dla kwestii społecznych specyfikę branżową (dominacja przemysłu bawełnianego, dość znaczny udział przemysłu wełnianego, od 1909 r. w niewielkiej skali przemysł jedwabny), zwrócić trzeba uwagę na zasadnicze różnice co do warunków pracy, płacy, zależności służbowej występujące między podstawowymi wydziałami przedsiębiorstwa włókienniczego. W dotychczasowych badaniach pomijano je, traktując przędzalnie i tkalnie, które tradycyjnie zatrudniały najwięcej kobiet, jako w pełni porównywalne środowiska pracy. Nie wchodząc w szczegółowe opisywanie różnic, poprzestańmy na wskazaniu, gdzie ich nieuwzględnienie zafałszowuje rzeczywistość historyczno-kulturową.

Powtarzanie za W.S. Reymontem i późniejszą beletrystyką, że kobiety pracujące w fabryce stawały się obiektem zainteresowania fabrykantów (s. 73), to nic innego jak nadawanie sankcji „naukowości” mitowi, literackiemu obrazowi, nie znajdującemu odpowiedniego potwierdzenia w rzeczywistości historycznej. Mityczny obraz fabrykanta przechadzającego się po halach fabrycznych lub przynaglającego robotników do porannego wyjścia do pracy z mieszkania w domu fabrycznym paraliżuje do dziś i jak widać skutecznie, podjęcie próby jego weryfikacji ${ }^{31}$. Warto więc przyjąć jako pewnik, że prawdopodobieństwo spotkania przez robotników „fabrykanta” - właściciela wielkiego przedsiębiorstwa włókienniczego w miejscu ich pracy, było bliskie zeru. W tkalniach robotnicy mieli bezpośredni kontakt z majstrami (podmajstrami) zmianowymi. Każdy z nich nadzorował w tkalni pracę partii krosien (od 24 do 36 maszyn w zależności od specyfiki przedsiębiorstwa). Majstrowie zmianowi podlegali majstrowi salowemu (obermajstrowi), dla którego tkacz, czy tkaczka nie byli partnerami w żadnym zakresie. Raz, dwa razy dziennie (a w ogromnej Nowej Tkalni scheiblerowskiej nie częściej niż raz w tygodniu) robotnik mógł spotkać majstra salowego, koordynującego pracę sali maszyn. Do rangi wydarzenia urastało pojawienie się dyrektora wydziału. Z kolei w przędzalni pracę prządek obsługujących po kilka lub kilkanaście przędzarek nadzorował majster salowy. Na niezrozumieniu specyfiki pracy w przędzalni zasadza się ubolewanie, że zatrudnione w niej kobiety nie mogły awansować (s. 57). Nie mogły, ponieważ nie było w ich otoczeniu stanowisk pracy, które mogłyby objąć. Majster przędzalnik był fachowcem, z udokumentowanym $\mathrm{z}$ reguły wykształceniem zawodowym, które przed 1914 r., a nawet

${ }^{31}$ Liczne przykłady przytacza M. A. Łukowska, Fabrykant tódzki we wspomnieniach robotników, Łódź 2007. 
później, było niedostępne dla kobiet ${ }^{32}$. Wypada też wiedzieć, że przed rozpoczęciem pracy na krośnie tkackim, trzeba je obłożyć, czyli m. in. założyć wał osnowowy, ważący ok. 50-80 kg. Pracę tę wykonywał majster. Czy kobieta mogła być majstrem tkackim? Z perspektywy gender studies byłoby to pożądane. Ucinałoby utyskiwanie nad brakiem możliwości awansu zawodowego kobiet tkaczek. Problem w tym, że z oczywistych powodów nikt do takiego rozwiązania się nie palił. Potrzeba użycia znacznej siły fizycznej przy obsłudze krosien tkackich, zwłaszcza szerokich, używanych do wyrobu tkanin ciężkich, pluszu, sprawiała, że wbrew twierdzeniu Autorki (,przy fabrycznych krosnach stały wyłącznie kobiety" - s. 56), liczni byli też tkacze. W tkalni, najbardziej sfeminizowanym wydziale zakładów scheiblerowskich, odsetek pracujących kobiet wynosił w 1885 r. - 57,5\%, w 1900 r. - 63,6\%, a w 1909 r. - 65,9\% ${ }^{33}$, zatem mężczyźni stanowili „u Scheiblera” co najmniej $1 / 3$ ogółu tkaczy. Zauważmy, że przywołane przedsiębiorstwo pod względem feminizacji załogi tylko nieznacznie ustępowało przodującym w tej mierze zakładom I.K. Poznańskiego (kobiety w nich, to odpowiednio 48,5\% i 53,4\% ogółu zatrudnionych). Załogi innych łódzkich fabryk włókienniczych sfeminizowane były w mniejszym stopniu. Pożyteczniej byłoby więc stosować „perspektywę kobiecą” do zjawisk potwierdzonych źródłowo, a nie do wyobrażeń o nich.

Brak możliwości awansu kobiet w obrębie fabryki włókienniczej nie był skutkiem regulacji wewnętrznych w przedsiębiorstwie, chęci lub niechęci jego właściciela, lecz konsekwencją posiadania lub nieposiadania określonych cech fizycznych, a także efektem systemowego, prawnego statusu wszystkich kobiet. Mimo to w obrębie przędzalni, podobnie i w tkalni, istniała specyficzna forma „awansu”. Robotnica wyróżniająca się zdolnościami manualnymi, zręcznością, mogła zostać skierowana do obsługi maszyny rzadziej ulegającej awariom, wydajniejszej. Praca kobiety była wówczas nieco mniej uciążliwa. Robotnica unikała kar za częste zrywanie przędzy, czy wady w tkaninie, ale głównym beneficjentem tej zmiany pozostawał i tak właściciel przedsiębiorstwa, ponieważ rosła wielkość produkcji, a w konsekwencji zysk. Teza, że

XIX-wieczne robotnice odbierały podrzędną sytuację zawodową i społeczną jako zgodną z obowiązującym normami społecznymi. Nie podejmowały rywalizacji z mężczyznami i uważały tę sytuację za naturalną (s. 58),

jest tylko przeniesieniem spojrzenia współczesnych socjologów na sprawę nierówności płci, do realiów przełomu XIX i XX w. z nadzieją, że cokolwiek ono

${ }^{32}$ Należałoby się odwołać do realiów XX w. Czy w łódzkich przedsiębiorstwach włókienniczych były kobiety zatrudniane na stanowiskach dyrektorów przędzalni?

${ }^{33}$ W. Puś, S. Pytlas, Dzieje Łódzkich Zakładów Przemystu Bawetnianego im. Obrońców Pokoju „Uniontex” (d. Zjednoczonych Zakładów K. Scheiblera i L. Grohmana w latach 1827-1977, Warszawa-Lódź 1977, s. 126. 
wyjaśni. Tymczasem, z powodów wyżej przedstawionych, rywalizacji zawodowej kobiet z mężczyznami w fabryce włókienniczej przełomu XIX i XX w. być nie mogło.

Wspomniany „awans” mógł też dojść do skutku w sposób niewygodny do interpretacji „z perspektywy kobiecej”. Bo cóż powiedzieć o takiej sytuacji:

Wiele spośród młodych weberek [tkaczek - przyp. K.P.W.] nie tylko, że nie broni swej godności kobiecej, ale ją traci zupełnie i staje się współwinowajczyniami bezeceństw wyprawianych przez majstrów [...]. Majstrowie darzą naturalnie te weberki wielkimi względami. Majstra do warsztatu doprosić się nie można. Lecz niech która z nich mrugnie, pędzą na wyścigi ${ }^{34}$.

Opis ten współbrzmi z żyrardowskimi wspomnieniami Pawła Hulki-Laskowskiego ${ }^{35}$. Obraz zjawiska jest więc znacznie bardziej złożony niż przedstawiany piórami aktywistów socjalistycznych w latach rewolucji 1905-1907 r. ${ }^{36}$

Wspomniany wyżej brak pogłębionych, źródłowych badań nad społeczeństwem Łodzi epoki kapitalizmu rodzi pokusę odwoływania się do ustaleń sformułowanych dla innych środowisk. Za sprawą licznych publikacji Anny Żarnowskiej oraz kręgu jej współpracowników i kontynuatorów, dysponujemy szeroką wiedzą o społeczeństwie Warszawy. Niestety, snucie porównań między proletariatem warszawskim i łódzkim jest nieuzasadnione, nietrafne i prowadzi do mylnych wniosków. Ta nieprzystawalność jest szczególnie widoczna właśnie w rozważaniach nad miejscem i rolą kobiet robotnic.

Co najmniej do końca XIX w. dominował w Warszawie proletariat rzemieślniczy. Dopiero w przeddzień I wojny światowej przewagę liczebną zdobyli robotnicy fabryczni ${ }^{37}$. Najliczniejsze ich grupy stanowili metalowcy oraz robotnicy zatrudnieni przy produkcji konfekcji ${ }^{38}$. Ci ostatni pracowali w dużym rozproszeniu, znaczna część w systemie chałupniczym ${ }^{39}$. Większość zatrudnionych w przemyśle konfekcyjnym stanowiły kobiety ${ }^{40}$. Przed 1914 r. było w Warszawie jedynie ok. 10 dużych fabryk włókienniczych, zatrudniających po 350-600 osób. Tymczasem w Łodzi tylko zakłady scheiblerowskie zatrudniały ok. 8 tys. robotników. $\mathrm{Na}$ warszawskim rynku pracy, na jedną robotnicę przypadały ponad trzy służące [pomoce domowe - przyp. K.P.W.], podczas gdy w Łodzi liczba robotnic była wyższa (!) niż kobiet zatrudnionych jako służba domowa. Co więcej,

${ }^{34}$ S. Martynowski, Łódź w ogniu, Łódź 1931, s. 104.

35 „Pewnego razu, gdy do fabryki przyszedłem o godzinę wcześniej, aby wyrównać duże zaległości, sprzątaczka podchodziła do mnie i proponowała coś 'na chybcika', bo nikogo nie ma” (P. Hulka-Laskowski, Mój Żyrardów, Warszawa 1958, s. 124).

${ }^{36}$ K. Woźniak, Między robotnikiem a fabrykantem..., s. 262.

${ }^{37}$ A. Żarnowska, Robotnicy Warszawy na przetomie XIX i XX wieku, Warszawa 1985, s. 16.

38 Tamże, s. 17.

39 Tamże, s. 18.

${ }^{40}$ Tamże, s. 19. 
po przybyciu do Warszawy dziewczęta najczęściej znajdowały zarobek w służbie domowej lub innych usługach, w szwalniach, warsztatach bieliźniarskich, gorseciarskich, rzadko

- w fabryce [podkr. K.P.W. $]^{41}$.

W ostatniej ćwierci XIX w. około połowa proletariatu Warszawy legitymowała się urodzeniem na wsi, w Łodzi było to ok. $75 \%$. Wszystkie wymienione wyżej uwarunkowania sprawiły, że już przed 1914 r. w Łodzi ukształtował się etos kobiety włókniarki, a w Warszawie - nie. Wskazane różnice sprawiały, że zarówno pozycja, jak i perspektywy awansu zawodowego i społecznego kobiet robotnic w Łodzi i Warszawie były diametralnie różne ${ }^{42}$. Nie przekonują też zupełnie liczne w tekście odniesienia do znanego Autorce z własnych badań źródłowych środowiska nauczycielek (s. 55-57), zwłaszcza w odniesieniu do możliwości zarobkowych i awansu zawodowego. Obie grupy społeczne są nieporównywalne.

M. Sikorska-Kowalska powtarza pokutującą od lat w literaturze, sloganowo już brzmiącą opinię o dążeniu robotnic, by „ubierać się tak jak żony fabrykantów" (s. 74). Do tego uogólnienia trzeba dodać pytanie: to znaczy jak? Wystarczy sięgnąc do bogatego źródła, jakim są fotografie (portrety indywidualne, portrety zbiorowe robione w trakcie spotkań towarzyskich), przedstawicielek łódzkiej burżuazji. Wystarczy zinterpretować wyznanie Heleny Anny Geyer, która zawiadomiona o śmierci córeczki (1882 r.), jedzie powozem na miejsce wypadku „bez kapelusza”! I ten brak obowiązkowej w jej środowisku części stroju odczuwa na tyle mocno, że po latach przywoła go w swych wspomnieniach ${ }^{43}$. Konia z rzędem temu, kto wskaże wykonaną przed 1914 r. fotografię łódzkiej robotnicy, a będzie to zwykle portret wykonany z jakiejś szczególnej okazji w atelier lub portret zbiorowy na dziedzińcu fabrycznym, w kapeluszu na głowie. Taka „modnisia” zostałaby wykpiona w swoim środowisku. Próby noszenia kapeluszy zapewne były, potwierdza to Autorka dla 1905 r. (s. 77), ale - tu pikanteria tej sytuacji - kobiety noszące je, były szykanowane w swoim środowisku za uleganie zbytkowi, który nie przystoi robotnicy. Szkoda, że ten paradoks nie został skomentowany. Kapelusze, zgodne kształtem z obowiązującą modą, zaczną robotnice nosić przy świątecznych okazjach dopiero w latach $20 . \mathrm{XX}$ w. ${ }^{44}$ Nawet w bardziej tolerancyjnej pod tym względem Warszawie, dopiero po 1918 r. kobiety z warstwy drobnomieszczańskiej będą ,paradowały w kapeluszach przy każdej okazji, podkreślając

${ }^{41}$ Tamże, s. 35.

${ }^{42}$ Materiału porównawczego dla środowiska łódzkich włókniarek trzeba szukać w Żyrardowie, Pabianicach, Sosnowcu, w węższym zakresie w Kaliszu i Częstochowie.

${ }^{43}$ H.A. Geyer, Z mojego życia. Wspomnienia z lat 1844-1914 / Aus meinem Leben. Erinnerungen aus den Jahren 1855-1914, pod red. K.P. Woźniaka z komentarzem językoznawczym J. Riecke, Łódź 2002, s. 25.

${ }^{44}$ Tego okresu dotyczy cytowany przez Autorkę (s. 74) opis A. Wóycickiego, oparty w głównej mierze na spostrzeżeniach dotyczących środowiska robotników warszawskich. 
w ten sposób, że nie należą do klasy robotniczej" ${ }^{45}$. Wspomniana już H.A. Geyer, relacjonując przebieg śniadania jedzonego z mężem, wspomina, że Gustaw przyniósł jej szlafrok i czepek ${ }^{46}$. Nie znam przekazu, który mówiłby o łódzkiej robotnicy spożywającej śniadanie w czepku i szlafroku. Podobnie nie znam żadnego przekazu o chęci posiadania przez nią amazonki (stroju do jazdy konno), niezbędnego elementu garderoby fabrykanckiej córki, spędzającej czas w rodzinnej ,wilegiaturze” lub „u wód”. Także w tym przypadku odwołać się można do archiwalnych fotografii, choćby Marii Buchholtz, wnuczki Karola Scheiblera ${ }^{47}$. To oczywiście przykłady najjaskrawsze, ale skutecznie odsyłające do rekwizytorni określeń nieadekwatnych takie sformułowania, które pomijają kontekst społeczno-kulturowy opisywanych zjawisk. W świetle aktualnej wiedzy, ,ubierać się jak żony fabrykantów", znaczy nie więcej, niż naśladować ich odzież co do formy, kroju. Zupełnie nierozpoznany pozostaje wpływ aktualnej mody na zmiany form odzieży noszonej w łódzkim środowisku robotniczym. W poszukiwaniach można wzorować się na opublikowanych wynikach badań prowadzonych w Żyrardowie w latach 70. XX w. i już wówczas uwzględniających zjawisko ,feminizacji biedy", widoczne także w odzieży ${ }^{48}$. Otwartym pozostaje pytanie, czy rytm zmian w formach noszonych ubrań był podobny we wszystkich środowiskach mieszkańców Łodzi, czy też można zaobserwować zjawisko analogiczne do „opadania dóbr kulturowych”, właściwe dla kultury tradycyjnej ${ }^{49}$. Dopiero uwzględniając wszystkie te uwarunkowania, można dociekać, na ile i w jaki sposób robotnice (i robotnicy) łódzcy starali się ubierać ,jak fabrykanci”.

Nadmierne zaufanie do przekazu literackiego, publicystycznego skutkuje wspomnianymi już w uwagach do tekstu K. Śmiechowskiego uproszczeniami i niedopowiedzeniami. Do kategorii licentia poetica należy zaliczyć przekaz mówiący o zabawach tanecznych (tak trzeba tłumaczyć niemiecki termin „Tanzkränchen”) w sali Vogla (miał na imię Ignacy), w których uczestniczyć mieli ,zarówno robotnicy, jak i ich chlebodawcy" (s. 76). Chlebodawcy, czyli kto? Nie spodziewałbym się w tym popularnym miejscu sobotnich zabaw przedstawicieli najdrobniejszej nawet łódzkiej burżuazji. Bywali natomiast przedstawiciele drobnomieszczań-

45 J. Świdrowski, Moja droga w świat. Wspomnienia 1906-1939, Warszawa 1980, s. 46-48; cyt. za: A. Żarnowska, dz. cyt., s. 11.

46 A. Żarnowska, dz. cyt., s. 19.

47 K. P. Woźniak, Supraśl - 500 lat. Zarys dziejów, Supraśl-Białystok 2000, s. 78.

48 Klasycznym przykładem analizowania ubioru robotniczego z uwzględnieniem ,feminizacji biedy", jest tekst Andrzeja Woźniaka, Niedziela ubogiej damy, czyli o modzie wśród żyrardowskich robotników na przełomie XIX i XX wieku, [w:] Materiaty do etnografii miasta, pod red. A. Stawarza, Żyrardów 1992, s. 12-27. Zob. też: tenże, Badania nad obyczajem i moda w środowisku robotniczym Żyrardowa, „Łódzkie Studia Etnograficzne”, t. 21, 1979, s. 35-54.

49 I. Kabat, Opadanie dóbr kulturowych, [w:] Słownik etnologiczny. Terminy ogólne, pod red. Z. Staszczak, Warszawa-Poznań 1987, s. 268-269. 
stwa, właściciele zakładów rzemieślniczych i usługowych, niedostrzeżeni przez Autorów książki jako ważni uczestnicy relacji zachodzących między warstwami proletariatu i na jego obrzeżach.

Całkowitym nieporozumieniem jest interpretacja sensu zwyczaju zwanego „klocki”. Zdaniem Autorki, jego celem było „piętnowanie starych panien” i „była to zabawa brutalna i poniżająca kobiety” (s. 60, 63). „Podczas 'klocków' środowisko robotnicze wyrażało pogardę dla kobiet samotnych", twierdzi M. Sikorska-Kowalska (s. 63-64). W rzeczywistości „klocki” były kontynuacją zwyczaju obecnego w kulturze polskiej od co najmniej schyłku XVI w., zakorzenionego zarówno w środowisku wiejskim, jak i miejskim. Znamy go m. in. z XVII-wiecznego przekazu Stanisława Serafina Jagodyńskiego, z wiek późniejszego opisu Jędrzeja Kitowicza i wielu, wielu innych późniejszych, także autorstwa badaczy kultury. Liczne ślady tego zwyczaju zachowały się w literaturze sowizdrzalskiej i materiałach folklorystycznych ${ }^{50}$. Na warszawskich ulicach zwyczaj praktykowany był jeszcze w $1914 \mathrm{r}^{51}$,Klocki” miały charakter sankcji dla tych panien i kawalerów [podkr. K.P.W.], którzy w okresie karnawału nie zmienili stanu cywilnego. „Kawalerom przyczepiano ogon świński lub króliczy, szkielet śledzia lub jego sylwetkę wyciętą z papieru, czasem kartkę z uszczypliwym napisem"s2. Trzeba dużej dozy fantazji, aby w czynnościach tych widzieć poniżanie, upokarzanie kobiet. Można wyrazić obawę, czy np. wielkanocny śmigus, niosący ze sobą oblewanie dziewcząt wiadrami zimnej wody, moczenie ich w sadzawkach, stawach, nie zostałby uznany w ,perspektywie studiów kobiecych” za przejaw męskiego sadyzmu. „Klocki” miały charakter zwyczajowej sankcji środowiskowej i stanowiły pretekst do zabawy [podkr. K.P.W.], by ,śmiech był na sali [fabrycznej]"53. Trudno mi ukryć zdziwienie, że uzasadniając swoje, demonizujące zwyczaj wywody, Autorka powołała się na mój tekst, wskazując w dodatku stronę, gdzie o „klockach” nie znajdziemy ani słowa. Szkoda, że Autorka nie zauważyła istotnej konkluzji moich rozważań, być może jako niezgodnej z ,perspektywą studiów kobiecych”: „Na terenie fabryki funkcja ludyczna uzyskała dodatkowy wymiar. 'Klocki' rozśmieszały robotników, wprowadzały swobodniejszą atmosferę w miejscu pracy" ${ }^{54}$. Liczne relacje łódzkich robotników mówią też wyraźnie, że „najcenniejszy materiał do napastowania” stanowili majstrowie, którzy w tym

${ }^{50}$ K. Woźniak, „Klocki”. W poszukiwaniu źródet zwyczaju, [w:] Materiały do etnografii miasta, pod red. A. Stawarza, Żyrardów 1992, s. 37-45.

${ }^{51}$ M. Gabryś-Sławińska, Warszawska ulica na łamach „Tygodnika Ilustrowanego” (1914), [w:] Ulica - zautek - bruk. Z problematyki miasta w literaturze drugiej połowy XIX i poczatku XX wieku, pod red. K. Badowskiej i A. Janiak-Staszek, Łódź 2013, s. 161, przyp. 66.

${ }_{52}$ B. Kopczyńska-Jaworska, Zwyczaje i obyczaje ludności Łodzi, [w:] Łódź. Dzieje miasta, t. 1. Do 1918 r., pod red. B. Baranowskiego i J. Fijałka, Warszawa-Lódź 1980, s. 505; I. Lechowa, Relacje wieś - miasto w tradycji robotniczej Łodzi, „Łódzkie Studia Etnograficzne”, t. 15, 1973, s. 76-77.

${ }^{53}$ K. Woźniak, ,Klocki”..., s. 38.

${ }^{54}$ Tenże, Tradycje łódzkiej kultury robotniczej, „Osnowa” 1981, nr 1, s. 82. 
dniu znajdowali dla siebie zajęcia poza halami produkcyjnymi, aby nie narażać się na uszczypliwe, choć w atmosferze zabawy formułowane żarty podległych im robotników ${ }^{55}$. Tego, jakże ważnego aspektu relacji środowiskowych, z perspektywy „studiów kobiecych”, niestety, nie widać.

Należy mieć nadzieję, że „perspektywa kobieca” przyjęta w dalszych badaniach nad społeczeństwem Łodzi w XIX i na początku XX w. zyska zarówno konieczną szczegółowość, jak i pełniejsze osadzenie w kontekście zjawisk kulturowych, a poszukiwania będą prowadzone z poszanowaniem faktografii: Ludwik Geyer nie mógł nikogo zatrudniać ani w 1885 r., ani w 1892 r. (s. 51), ponieważ od 1869 r. nie żył. Podobnie Ludwik Grohman; nie zatrudnił nikogo w 1892 r. (s. 51), bo nie żył od trzech lat.

$* * *$

Trzeci tekst pomieszczony w książce wyszedł spod pióra Kenshi Fukumoto, japońskiego doktoranta w Instytucie Historii UŁ. Na 19 stronach podjął się on przedstawienia problemu Rekonstrukcja narracji robotników fabrycznych $w$ Łodzi 1864-1914. Picie alkoholu, walka o życie i modlenie się. Oryginalny tekst w języku angielskim uzupełnia pięciostronicowe polskie streszczenie. Co prawda Autor twierdzi (s. 107), że w tytule jego tekstu ,został użyty zwrot refleksja postkolonialna", ale nie ma go ani w oryginalnym tytule angielskim, ani w tytule polskiego streszczenia, ani w spisie treści. Odnoszę wrażenie, że walory tekstu K. Fukumoto zostały poważnie umniejszone polskim nieudanym tłumaczeniem, zaś sam tekst angielski jest zbyt ogólnikowy i hermetyczny, by przekonać czytelnika, że środowisko łódzkich robotników przełomu XIX i XX w. może być traktowane podobnie, jak hinduscy autochtoni w Indiach, w latach panowania brytyjskiego. Wydaje się, że niezależnie od perspektywy swoich dociekań, zapożyczonej od Gayatri Chakravorty Spivak, Autor odwołał się do modnych obecnie w nauce anglosaskiej i niemieckiej teorii dotyczących środowisk defaworyzowanych. Posługiwanie się w odniesieniu do robotników łódzkich pojęciem ,,podległości”, które charakteryzuje wszystkie społeczności ukonstytuowane hierarchicznie, może być traktowane tylko jako figura retoryczna. Z wyjaśnień K. Fukumoto wynika, że w Japonii, w podejmowanych współcześnie badaniach historycznych nastąpił zwrot ku daniu możliwości dojścia do głosu tym grupom społecznym, którym ten głos odebrano. Łódzki proletariat potraktowany został przez Autora jako „bezgłośna” grupa, którą charakteryzowało nadużywanie alkoholu, walka o byt (jej przejawem rewolucja 1905-1907 r.) oraz fascynacja mariawityzmem, jako „,nowoczesnym zjawiskiem społecznym”, będącym swoistym panaceum na rozczarowanie rewolucją i zarazem nadzieją na religijną odnowę moralną (s. 102).

${ }^{55}$ Instytut Etnografii i Antropologii Kulturowej UŁ, Archiwum Zakładu Etnografii, sygn. B-1893; zob. też: sygn. B-1880, B-1882, B-1886, B-2033, B-2036. 
Autor nie przedstawia żadnych dowodów na to, że społeczność łódzkich robotników przełomu XIX i XX w. ujawniała cechy społeczeństwa postkolonialnego.

W moim głębokim przekonaniu zderzanie różnych punktów widzenia, różnych szkół badawczych, różnych wrażliwości wyrastających z odmiennych tradycji kulturowych powinno i może przynosić nowe sposoby interpretowania procesów społecznych, których - wydawałoby się - nie można już odczytać inaczej, niż mówią to znane nam ujęcia. Jest jednak pewne, dość istotne ograniczenie. Konfrontacje takie wymagają dość szerokiej wiedzy o przedmiocie badań. Nie dziwi zainteresowanie młodego japońskiego badacza problematyką mariawityzmu, ale odwoływanie się wyłącznie do organu prasowego mariawitów, bez wystarczającej znajomości i odniesienia się do wniosków zawartych w poświęconym im wcale niemałym piśmiennictwie, musi pociągnąć za sobą zarzut braku krytycyzmu badawczego ${ }^{56}$. Dla zrozumienie genezy mariawityzmu niezbędna jest wiedza o sytuacji kościoła rzymskokatolickiego w Królestwie Polskim po 1863 r. Niezbędne jest wyciągnięcie wniosków $\mathrm{z}$ faktu tworzenia pierwszych struktur parafialnych we wsiach i małych miasteczkach już u schyłku XIX w., a także ze szczególnej roli nadanej przez ruch mariawicki postaci Matki Boskiej Nieustającej Pomocy ${ }^{57}$. Na te aspekty wiedzy o mariawityzmie, powinni zwrócić uwagę Autorowi jego opiekunowie naukowi.

$$
* * *
$$

Omawiana książka rozczarowuje także pod względem opracowania redakcyjnego. Część zatytułowana Od redakcji, zawiera jedynie noty biograficzne o Autorach. Z kolei Wstęp, który prawdopodobnie jest Ich wspólnym tekstem, nie został w ogóle podpisany. Wyjątkowo niestarannie zestawiono bibliografię. Pominięto 5 z 11 tytułów czasopism („Dziennik Łódzki”, „Głos”, „Goniec Łódzki”, „Nowy Kurier Łódzki”, ,Ster”), z których materiały wykorzystano w książce. Nie wskazano archiwum przechowującego akta Starszego Inspektora Fabrycznego, a nazwę tego zespołu zniekształcono (powinno być: Starszy Inspektor Fabryczny Guberni Piotrkowskiej); pominięto też jedną z cytowanych jednostek (sygn. 4023, s. 68). Wśród opracowań pominięto co najmniej kilkanaście prac, m.in.: M. Bandurki, B. Filipowicza, M. Kotera (i zespołu), I. Lechowej (na s. 64 w przyp. 48

${ }^{56} \mathrm{Z}$ obszernej literatury, zob.: A. Rhode, Bei den Mariawiten. Eindrücke von einer neuen romfreien katolischen Kirche, Berlin 1911; J.K. Gajkowski, Mariavitensekte. Einige Blätter aus der neuesten Kirchengeschichte Russisch-Polens, b.m.w. 1911; S. Grelewski, Wyznania protestanckie $i$ sekty religijne w Polsce współczesnej, Lublin 1937; S. Rybak, Mariawityzm. Dzieje i współczesność, Warszawa 2011; A. Górecki, Mariawici i mariawityzm - narodziny i pierwsze lata istnienia, Warszawa 2011.

${ }^{57}$ R. Podgórski, Religijność wiernych Starokatolickiego Kościoła Mariawitów. Studium historyczno-socjologiczne, Kraków 1998, s. 17-44; T.D. Mames, Oświata mariawitów w latach 1906-1935, Warszawa-Bellerive-sur-Allier 2016, s. 81-82. 
błędny zapis tytułu jej artykułu), A. Majera, A. Rynkowskiej, A. Wiśniewskiego, B. Wojciechowskiej, S. Woszczyńskiej, K. Woźniaka oraz opracowania zbiorowe: Wspomnienia weteranów... i Łódzkie barykady. Z niewiadomych powodów Verdmon J.L., umieszczony został po nazwiskach na litere „W”. Z kolei tytuł jednego z podrozdziałów w tekście M. Sikorskiej-Kowalskiej, urasta, złożony kursywą (s. 10), do rangi tytułu jej tekstu.

Lektura książki przekonuje, że Autorzy (Redakcja?) nie dokonali choćby pobieżnej korekty tekstu. Pozostały więc w nim liczne błędy i ułomności (gramatyczne, ortograficzne, stylistyczne, logiczne), z których chyba najdotkliwsza to "wykolejenie społeczne" zamiast wykluczenia społecznego (s. 30). Inne dostrzeżone, to: „nazwał Łódź mianem” (s. 13); „bierna postawa wobec polityk” (s. 9-10); „podkreślić należy siłę fenomenu klasy robotniczej, która [...] urosła u progu XX w. na tyle, by stanowić istotny fenomen społeczno-polityczny" (s. 14); „starał będę się zrekonstruować” (s. 15); ,uwagi dotyczące zjawiska [...] jakim były kobiety” (s. 10); ,zamieszkały przez robotników” (s. 20); „ta szczególna obyczajowość ta” (s. 27); „w rodzaju podanych przeżeranie [?] wyżej” (s. 29); „stan mieszkali jest rozpaczliwy” (s. 38); „badania nad klasą robotniczą [...] stanowiły dla niej start do badań nad historią kobiet” (s. 53); „stan oświaty wśród robotników stanowił obraz tragiczny" (s. 53); ,robotnice [...] stanowiły jednak na przełomie wieku XIX i XX zjawisko masowe” (s. 54); „w momencie pojawienia się w tkance miejskiej, natychmiast stały się obiektem dyskryminacji" (s. 55). Trudno dopatrzeć się logiki w zdaniu: „,ódź nie była bynajmniej miastem robotników, którzy byli ofiarami nieustającego głodu mieszkaniowego, a ich warunki życia szokowały ówczesnych higienistów i społeczników" (s. 8). Pisanie o Warszawie „stolica” (s. 34), jest chyba dla rozpatrywanego okresu nadużyciem. Konsekwentnie nieortograficznie pisany jest przymiotnik „rzymskokatolicki”, podobnie „postkolonialny” (s. 109-110). Zdarzają się błędy literowe zniekształcające nazwiska (M. Sikorksa, s. 63, 87; Heintzel, Biederman, s. 96; A. Titkow, s. 116) i inne: „nic tylko w dyskursie” (s. 22), ,idąc na Wókę”, zamiast: na Wólkę (s. 28), „onferencja” (s. 97, przyp. 33), „watro” zamiast warto (s. 109). Liczne są błędy interpunkcyjne (np. „W artykule tym., autor” - s. 61; użycie wielkiej litery w rzeczowniku pospolitym po przecinku). Zdarza się powtórzenie części zdania (s. 108, przedostatni akapit), wadliwie skonstruowany przypis (s. 17, przyp. 24; s. 57, przyp. 29; s. 65 , przyp. 55). Żadne reguły edytorskie nie są zachowane w tekście K. Fukumoto (s. 87-105), w którym zdarza się nawet połączenie w jednym zapisie bibliograficznym sposobu angielskiego, polskiego i niemieckiego (s. 91, źródło w tabeli 1).

Omawiana książka, jak wiele innych, publikowanych na przestrzeni kilku ostatnich lat, dowodzi niepokojących skutków parametryzacyjnej pogoni „za punktami” autorów ze środowisk akademickich. Pośpiechowi towarzyszy 
brak staranności zarówno w warstwie merytorycznej, jak i edytorskiej. Szkoda, że przystaje na to oficyna uniwersytecka, broniąca się jedynie formułą: „publikacja bez opracowania redakcyjnego i korekty w Wydawnictwie UŁ”. Wątpliwości budzi też dobór recenzentów wydawniczych. Trudno oczekiwać od badacza specjalizującego się w innej epoce i nie znającego realiów miejsca opisywanego w książce, wnikliwych uwag mogących udoskonalić jej treść. W zapomnienie odeszła praktyka dyskutowania na różnych forach fragmentów przygotowywanych do druku prac, co zawsze służy ich doskonaleniu. Iluzoryczna staje się opieka nad doktorantami, a tradycje w tym zakresie przywołać można świetne, jak choćby prowadzone w Instytucie Historii UŁ seminarium doktorskie prof. Józefa Śmiałowskiego, z którego w latach 80 . XX w. wyszedł m.in. świetny znawca przemysłu Królestwa Polskiego, Kazuo Fuji, późniejszy profesor uniwersytetu w Kobe (Japonia). Jedna z moich uniwersyteckich Mistrzyń, prof. Krystyna Śreniowska, starała się w swoich, jakże często surowych recenzjach, znajdować jakiś walor komentowanych prac. Zdarzało się, że pisała: „książka zaleca się piękną okładką". Pozwolę sobie frazę tę powtórzyć.

Słowa kluczowe: artykuł recenzyjny, robotnicy, Łódź, XIX wiek

Keywords: review article, workers, Łódź, XIX ${ }^{\text {th }}$ century 